\title{
Sporicidal activity of chemical and physical tissue fixation methods
}

\author{
N J Vardaxis, M M Hoogeveen, M E Boon, C G Hair
}

\begin{abstract}
Aims-The effects of alcohol based fixation and microwave stimulated alcohol fixation were investigated on spores of Bacillus stearothermophilus and Bacillus subtilis (var. niger).

Methods-Spores were exposed to $10 \%$ formalin, or different concentrations of various alcohol containing fixatives (Kryofix/Spuitfix). Adequate controls were also set up in conjunction with the test solutions. The spores were immersed with and without adjunctive microwave stimulation in the various solutions tested. Possible surviving spores were recovered in revival broth and after incubation, and Gram staining viable counts were performed.

Results-Alcohol based fixatives did not have a sporicidal effect on $B$ stearothermophilus or $B$ subtilis (var. niger) spores, and microwave stimulated alcohol fixation at $450 \mathrm{~W}$ and up to $75^{\circ} \mathrm{C}$ did not have a sporicidal effect.

Conclusions-When alcohol based fixatives are used for fixation, precautions should be taken with the material thus treated, as it may contain viable spores or other pathogens, which are destroyed after 24 hours of formalin treatment. Of the physicochemical methods tested involving microwaving, none was successful in eliminating viable spores from the test material.

(F Clin Pathol 1997;50:429-433)
\end{abstract}

Department of

Medical Laboratory

Science, Royal

Melbourne Institute of

Technology, Bundoora, Australia

N J Vardaxis

C G Hair

Leiden Cytology and Pathology Laboratory, Groenesteeg, Leiden,

The Netherlands

M M Hoogeveen

M E Boon

Correspondence to: Associate Professor N J Vardaxis, Department of Medical Laboratory Science, Royal Melbourne Institute of Technology, Plenty Road, Bundoora 3083, Australia. email:vardaxis@rmit.edu.au

Accepted for publication 26 February 1997
Keywords: bacterial endospores; chemical fixation methods; microwave treatment; formalin; sporicidal agents

Formaldehyde is a colourless, pungent, irritant, highly reactive gas that is water soluble. Because of its innate reactivity and instability it is marketed in aqueous solution (formalin) ranging from $37 \%$ to $50 \%$ formaldehyde by weight, which may have $10-15 \%$ added methanol to prevent polymerisation. A $10 \%$ widely as an effective fixative. Formaldehyde is a strong irritant and its local adverse reactions predominate over any possible systemic effects. ${ }^{1}$ Dermal sensitisation reactions are caused by formaldehyde in approximately $4 \%$ of people patch tested, making this substance dermatitis. Repeated application of higher concentrations of formaldehyde induces sensitisation in about $8 \%$ of male subjects, but with solution of formalin $(37 \% \mathrm{H}$.CHO) is used the 10th most commonly incriminated agent in
Table 1 Adverse effects of formaldehyde exposure

\begin{tabular}{ll}
\hline Health effects reported & $\begin{array}{l}\text { Approximate formaldehyde } \\
\text { concentrations (ppm) }\end{array}$ \\
\hline None & $0-0.5$ \\
Odour threshold & $0.05-1.50$ \\
Eye sensation/irritation & $0.05-2.0$ \\
Upper airway irritation & $0.10-25$ \\
Lower airway/pulmonary effects & $5-30$ \\
Pulmonary oedema/ & $50-100$ \\
$\quad$ inflammation & 100 \\
Death &
\end{tabular}

Table adapted from Singer, $1990 .^{4}$

lower concentrations (about $2 \%$ ) the incidence is only about $5 \%$ or less. A few reports have suggested that inhaling formaldehyde might also lead to sensitisation, but these have been anecdotal and the findings have not been supported by definitive diagnoses. Thus it appears that the primary irritant effect of formaldehyde is the usual cause of local adverse reactions. ${ }^{2}$

Approximately $60-90 \mathrm{ml}$ of formalin is quoted as the fatal oral dose. Ingestion may cause various symptoms which are related to the amount of formalin ingested and to variations in individual susceptibility. Headaches, corrosion of the gastrointestinal tract, oedema of the lungs, fatty change of the liver, renal tubular necrosis, loss of consciousness, and vascular collapse have all been described, as summarised in table $1 .{ }^{14}$ In animal testing formaldehyde has not been found to cause reproductive toxicity or to have teratogenic effects. However, concerns have been raised over the recent finding that it has mutagenic activity in certain test systems and corresponding carcinogenicity in rodents. While the exact mechanism of the mutagenic action remains unknown, a recurrent finding in several test systems was that formaldehyde produces crosslinks within DNA which are frequently recognised and repaired by the DNA repair enzymes present in those cells. The rodent carcinogenicity tests reveal a steep dose-response curve, strongly suggesting a definite threshold for this toxicity. ${ }^{2}{ }^{3}$ The possible carcinogenicity of formaldehyde in humans has been debated, and some investigators have cited the significantly higher rate of brain tumours and leukaemia among embalmers, anatomists, and pathologists as evidence for this carcinogenic action. ${ }^{4}$

Direct toxic effects of formaldehyde on the mucous membranes (table 1), and many other (often vague) user complaints such as impaired memory and dexterity, ${ }^{4-6}$ have led to the development of alternative fixatives not containing aldehydes, but based on ethyl alcohol in combination with a variety of other chemical 
agents. The use of alcohol containing fixatives is of great health benefit to clinical personnel and laboratory technicians. Some laboratories are currently using alcohol based fixation and many others are considering it as an alternative to formalin. Alcohol based fixation has been standard in most haematological and cytological applications but because of its significant shrinkage effect on tissue it has not been preferred as a standard method of fixation of tissue blocks. Alcohol based fixation of tissue blocks has been employed for tough, solid organs or for some tumours that are unlikely to show much artefactual shrinkage. As well as being safer to use than formalin, alcohol based fixation offers other advantages: better staining of fixed tissues with some of the aniline stains, improved preservation of some diseased tissues (for example, in amyloidosis), and also, importantly, preservation of the antigenic nature of most tissue elements, such that histochemical and antibody mediated staining techniques may be applied to the tissue without need for antigen retrieval, as is often the case with formalin fixed tissue..$^{78}$

It is known that formalin or glutaraldehyde fixation will in time kill any microorganisms that are present in a tissue sample that is immersed in these fixatives. ${ }^{9}$ Such fixation methods are therefore expected to be effective sterilants of clinical material. The types of microorganism that are of a particular concern are the bacterial endospores, as it is these which will survive the most adverse chemical and physical environmental conditions. In most routine applications, formalin or glutaraldehyde fixation is carried out for time periods that usually allow tissue and fixative contact for at least 24 hours. At the concentrations used and for the times recommended, aldehyde fixatives may be considered to be sporicidal and thus effective as tissue sterilants. ${ }^{10}$

When various mixtures of alcohol and polyethylene glycol (PEG) are used as fixatives, for example Kryofix or Spuitfix, the fixation of tissue is excellent; however, the sterilising effects on clinical material so fixed have not been investigated. It is known that $70 \% \mathrm{wt} / \mathrm{vol}$ alcohol will kill many Gram positive and Gram negative bacteria, some viruses, and some fungi, justifying its use as an effective antiseptic and disinfecting medium in many applications. However, alcohol is quite ineffective in destroying all forms of microorganisms, especially bacterial spores and the acid fast bacilli. ${ }^{11}{ }^{12}$ Indeed, alcohols are often used in the laboratory to selectively isolate the resistant, spore forming microbes while destroying all others. ${ }^{13}$

In a laboratory handling clinical material, it is highly probable that much of the material will be contaminated by many different forms of microbes. Although spore contamination is not likely to be a routine finding in much of the material that is processed by a laboratory, it is important to remember that some serious diseases may be caused by spore forming microbes, including tetanus, gas gangrene, anthrax, botulism, and gastroenteritis. If alcohol containing fixatives are used in laboratories handling clinical specimens, it is in the interests of occupational health and safety and of laboratory staff wellbeing to investigate the sterilising effects of alcohol-PEG mixtures used as fixing agents.

Bacillus stearothermophilus or Bacillus subtilis spore contamination of material to be sterilised is one of the standard methods of testing sterilisation efficiency of various procedures designed to kill or destroy microbes in various materials. ${ }^{14-16}$ The extreme resistance of bacterial spores makes them ideal for use in testing the efficiency of various physical and chemical sterilisation methods. ${ }^{17} B$ stearothermophilus spores survive five minutes at $121^{\circ} \mathrm{C}$ in a steam steriliser, but are killed within 15 minutes at $121^{\circ} \mathrm{C}$ in these sterilisers (Unipath Ltd, Basingstoke, UK: Oxoid, product information). Obviously such high temperatures are undesirable when fixing tissue as they are detrimental to tissue morphology and architecture. The temperatures attained in microwave assisted fixation of tissue are seldom above $55^{\circ} \mathrm{C}$, but such treatment may not have a sporicidal effect even when the physical and chemical methods of alcohol and microwave treatment are used in combination. ${ }^{17} 18$

The spores of $B$ stearothermophilus (ATCC 7953) and of $B$ subtilis (ATCC 9372) were chosen as the test organisms in the experiments reported here because of their extreme resistance. It was reasoned that if these spores were killed by the fixation methods investigated, there would be a very high probability that all microorganisms in the material would be killed by the treatment. Microwave assistance is often used as an adjunct to alcohol containing fixatives. Because of the known inability of alcohol to destroy spores, and the reported success of microwave sterilisation, we also decided to investigate whether microwave stimulated alcohol fixation had a sterilising effect on tissue samples which perhaps would not be sterilised by alcohol treatment alone.

\section{Methods}

The biological indicators used in this series of experiments were the spores of $B$ stearothermophilus ATCC 7953 (code BR23, Oxoid, Unipath, Basingstoke, UK; lot number R019525 001) and of $B$ subtilis var. niger, ATCC 9372 (Consulchem Pty, Scoresby, Victoria, Australia; lot number N33; batch 21 ). The recovery medium used for culture of treated spores was spore strip broth (code CM763, Oxoid, Unipath; lot number R019525 001) made up according to the manufacturer's instructions and sterilised in an autoclave for 20 minutes at $121^{\circ} \mathrm{C}$ and $1 \mathrm{bar}$. Sterility of the broth was assured by incubating uninoculated controls for seven days and visually inspecting for colour change in the medium daily and Gram staining of the broth at 2, 4, and 7 days. Viable counts were performed on the spore strips according to the instructions supplied by the manufacturers.

The various fixatives used were:

- $10 \%$ buffered formalin (Ajax Chemicals, Melbourne, Australia); Absolute, $70 \%$ wt/ vol, or $50 \% \mathrm{wt} / \mathrm{vol}$ ethyl alcohol (Ajax Chemicals, Melbourne, Australia); 
Table 2 Sporicidal effect of various fixative solutions

\begin{tabular}{|c|c|c|c|c|c|}
\hline \multirow[b]{2}{*}{ Treatment $\left(\right.$ at $\left.25^{\circ} \mathrm{C}\right)$} & \multirow{2}{*}{$\begin{array}{l}\text { Revival broth } \\
\text { incubation time }\left(56^{\circ} \mathrm{C}\right)\end{array}$} & \multicolumn{4}{|c|}{ Test solution spore immersion time } \\
\hline & & 24 hours & 48 hours & 7 days & 14 days \\
\hline $10 \%$ formalin & 24 hours & No growth & No growth & No growth & No growth \\
\hline & 48 hours & No growth & No growth & No growth & No growth \\
\hline Absolute or $70 \%$ or $50 \%$ & 24 hours & Growth & Growth & Growth & Growth \\
\hline $\begin{array}{l}\text { ethyl alcohol } \\
50 \% \text { PEG300 }\end{array}$ & 48 hours & & & & \\
\hline $50 \%$ PEG300 & $\begin{array}{l}24 \text { hours } \\
48 \text { hours }\end{array}$ & Growth & Growth & Growth & Growth \\
\hline $\begin{array}{l}\text { Neat or } 80 \% \text { or } 70 \% \text { or } 50 \% \\
\text { glycerol }\end{array}$ & $\begin{array}{l}24 \text { hours } \\
48 \text { hours }\end{array}$ & Growth & Growth & Growth & Growth \\
\hline Leiden fixative 1 & $\begin{array}{l}24 \text { hours } \\
48 \text { hours }\end{array}$ & Growth & Growth & Growth & Growth \\
\hline Leiden fixative 2 & $\begin{array}{l}24 \text { hours } \\
48 \text { hours }\end{array}$ & Growth & Growth & $\begin{array}{l}\text { No growth } \\
\text { No growth }\end{array}$ & $\begin{array}{l}\text { No growth } \\
\text { No growth }\end{array}$ \\
\hline Water & $\begin{array}{l}24 \text { hours } \\
48 \text { hours }\end{array}$ & Growth & Growth & Growth & Growth \\
\hline
\end{tabular}

- 50\% PEG 300 (Merck, Product No $807484) ; 100 \%, 80 \%, 70 \%$, and $50 \%$ glycerol (Ajax Chemicals);

- Leiden fixative 1 (Kryofix): $500 \mathrm{ml} \mathrm{96 \%}$ ethanol $+430 \mathrm{ml}$ demineralised water + $70 \mathrm{ml}$ PEG 300 (Merck, Product No 807484 ) with an end concentration of ethanol of $48 \%$;

- Leiden fixative 2 (Spuitfix): $800 \mathrm{ml} \mathrm{96 \%}$ ethanol $+130 \mathrm{ml}$ demineralised water +70 PEG 300 (Merck, Product No 807484) with an end concentration of ethanol of $77 \%$.

The spore strips were taken out of the glassine envelopes aseptically and placed in $50 \mathrm{ml}$ of each of the test solutions in a sterile bottle. They were left immersed in the test solution for 24 hours, 48 hours, 7 days, or 14 days, at room temperature. Once the test immersion time was attained the spore strip was removed from the test fixative solution aseptically, rinsed in $10 \mathrm{ml}$ of sterile spore strip broth (to remove traces of the sterilant), and then transferred aseptically to a glass culture bottle containing $50 \mathrm{ml}$ of the sterile spore strip broth. Both the rinse broth and immersion solutions were cultured. Controls included immersion of spore strips in water followed by incubation in sterile broth. The medium was lightly shaken and incubated for 24 hours $\left(\mathrm{O}_{2}, 55^{\circ} \mathrm{C}\right)$, upon which the broth was inspected and then incubated for a further 24 hours $\left(\mathrm{O}_{2}, 55^{\circ} \mathrm{C}\right)$, at the end of which the broth was inspected again for evidence of colour change and turbidity. Smears of the broth culture were made and Gram stained for microscopic examination. All of the tests were carried out in duplicate.

In addition, some of the fixatives with spores immersed in them were subjected to microwave treatment. The microwaving steps were performed in a BioRad microwave oven, model No $\mathrm{H} 2500$, running at $80 \%$ power $(450 \mathrm{~W})$. The temperature of the fixative during microwaving was monitored by a temperature probe which was sterilised with $3 \%$ hypochlorite solution and then rinsed with demineralised sterile water between each of the runs, which were as follows:

- Ethyl alcohol, absolute, 0.5 hours, $65^{\circ} \mathrm{C}$, $80 \%$ power $(450 \mathrm{~W})$.

- Ethyl alcohol, absolute, 0.5 hours, $75^{\circ} \mathrm{C}$, $80 \%$ power $(450 \mathrm{~W})$.

- Ethyl alcohol, $70 \%, 0.5$ hours, $65^{\circ} \mathrm{C}, 80 \%$ power $(450 \mathrm{~W})$.
- Ethyl alcohol, 70\%, 0.5 hours, $75^{\circ} \mathrm{C}, 80 \%$ power $(450 \mathrm{~W})$. Isopropyl alcohol, absolute, 0.5 hours, $65^{\circ} \mathrm{C}, 80 \%$ power $(450 \mathrm{~W})$. Isopropyl alcohol, absolute, 0.5 hours, $75^{\circ} \mathrm{C}$, $80 \%$ power $(450 \mathrm{~W})$.

- Leiden fixative $1,0.5$ hours, $65^{\circ} \mathrm{C}, 80 \%$ power $(450 \mathrm{~W})$.

- Leiden fixative $1,0.5$ hours, $75^{\circ} \mathrm{C}, 80 \%$ power $(450 \mathrm{~W})$.

- Leiden fixative 2, 0.5 hours, $65^{\circ} \mathrm{C}, 80 \%$ power $(450 \mathrm{~W})$.

- Leiden fixative $2,0.5$ hours, $75^{\circ} \mathrm{C}, 80 \%$ power $(450 \mathrm{~W})$.

- Water 0.5 hours, $65^{\circ} \mathrm{C}, 80 \%$ power $(450 \mathrm{~W})$.

- Water 0.5 hours, $75^{\circ} \mathrm{C}, 80 \%$ power $(450 \mathrm{~W})$

\section{Results}

Spore strips were disrupted in water in a blender so that the fibres were completely separated. Intact spores were present in the spore strips in a film made from the suspension and stained with a spore stain and Gram stain. The viable counts performed on the spore strips showed that the number of viable organisms recoverable from each spore strip was between 1.5 and $2.0 \times 10^{6}$. Control broths remained sterile.

The most effective sterilant among the solutions used was $10 \%$ formalin. Immersion of the spore strips in formalin for as little as 24 hours was an effective method of killing the microbes (table 2). At all concentrations tested, both alcohol alone and glycerol alone failed to kill the microbes, even after as long as 14 days' immersion in the test dilutions. Immersion in $50 \%$ PEG300 was only successful in destroying the microbes after seven days of immersion in the test solution. Exactly the same effect was observed with Leiden fixative 2, which was effective in killing the spores after seven days' immersion in the test solutions. Leiden fixative 1 did not destroy the spores even after 14 days' immersion in the test solutions.

All of the microwaving regimens followed proved ineffective in destroying the spores. Growth of the microbes was demonstrated in spore strips recovered from all of the solutions tested (table 3 ). These results were identical for both species of bacillus that were used.

\section{Discussion}

The use of formaldehyde and glutaraldehyde fixatives for clinical materials has a long history 
Table 3 Sporicidal effect of various fixative solutions combined with microwave treatment

\begin{tabular}{|c|c|c|c|}
\hline \multirow[b]{2}{*}{ Treatment } & \multirow{2}{*}{$\begin{array}{l}\text { Revival broth } \\
\text { incubation time } \\
\left(56^{\circ} \mathrm{C}\right)\end{array}$} & \multicolumn{2}{|c|}{$\begin{array}{l}\text { Test solution spore immersion time (with } \\
\text { microwaving at } 80 \% \text { power, } 450 \mathrm{~W} \text { ) }\end{array}$} \\
\hline & & $0.5 \mathrm{~h} / 65^{\circ} \mathrm{C}$ & $0.5 \mathrm{~h} / 75^{\circ} \mathrm{C}$ \\
\hline Absolute ethyl alcohol & 24 hours & Growth & Growth \\
\hline $70 \%$ ethyl alcohol & 28 hours & Growth & Growth \\
\hline Absolute isopropyl alcohol & $\begin{array}{l}24 \text { hours } \\
48 \text { hours }\end{array}$ & $\begin{array}{l}\text { Growth } \\
\text { Growth }\end{array}$ & $\begin{array}{l}\text { Growth } \\
\text { Growth }\end{array}$ \\
\hline Leiden fixative 1 & $\begin{array}{l}24 \text { hours } \\
48 \text { hours }\end{array}$ & $\begin{array}{l}\text { Growth } \\
\text { Growth }\end{array}$ & $\begin{array}{l}\text { Growth } \\
\text { Growth }\end{array}$ \\
\hline Leiden fixative 2 & $\begin{array}{l}24 \text { hours } \\
48 \text { hours }\end{array}$ & $\begin{array}{l}\text { Growth } \\
\text { Growth }\end{array}$ & $\begin{array}{l}\text { Growth } \\
\text { Growth }\end{array}$ \\
\hline Water & $\begin{array}{l}24 \text { hours } \\
48 \text { hours }\end{array}$ & $\begin{array}{l}\text { Growth } \\
\text { Growth }\end{array}$ & $\begin{array}{l}\text { Growth } \\
\text { Growth }\end{array}$ \\
\hline
\end{tabular}

and produces excellent fixation of tissue. However, the adverse health effects on laboratory personnel handling these substances have prompted the search for alternative fixation methods. One such method that is gaining acceptance and being increasingly used is alcohol based fixation. ${ }^{78}$ Although such methods of fixation are more acceptable to laboratory personnel and give good tissue fixation, ${ }^{19} 20$ the experiments described in this paper indicate that some caution is required in handling material thus fixed.

The alcohol based fixatives tested - with and without microwave incubation-proved inadequate to destroy the spores of $B$ stearothermophilus and $B$ subtilis. Hence it is probable that tissue fixed in alcohol based fixatives of the type described in this paper contain viable microbes. As the name of one of the test organisms implies (stearo $=$ wax; thermo $=$ heat; philus = loving), the spores of this organismand of many others - survive the heat of molten paraffin. So even tissue embedded in paraffin blocks may still contain viable spores. Nevertheless, we should point out that while spore strips were used in these experiments as a convenient source of the test organisms, this provides only an approximation of the situation in the laboratory where tissue samples are handled. Spore strips do not behave like tissue and one would need to exercise even greater caution with tissue samples, which may have a shielding or protective effect on the pathogens they contain.

In the experiments described here, the major group of microorganisms that are of concern are the spore forming bacteria of the genera Bacillus and Clostridium primarily. These organisms are the cause of serious and often life threatening diseases such as anthrax, tetanus, gas gangrene, botulism, and gastroenteritis of varying severity. However, it is important to realise that spore contamination of human tissue is relatively uncommon-one would be at much greater risk of contacting spores of bacillus or clostridium while pottering around in the garden.

Veterinary material processed histologically may often be contaminated by spores, and therefore the results of these experiments are of particular importance to laboratories that process much animal tissue. Several other important groups of microbes may also be resistant to alcohol based fixation methods- for example members of the genus Mycobacterium, several of which are capable of causing human tuberculosis. Some viruses have been shown to be resistant to alcohol as well.

Personnel working in cytology and pathology laboratories routinely handling diseased tissue are mainly concerned about HIV, hepatitis B and $\mathrm{C}$ viruses, other blood borne pathogens that are likely to contaminate tissue. While it has been suggested that alcohol and heating to $65^{\circ} \mathrm{C}$ will be rapidly effective in destroying the viability of non-sporing pathogens, further studies with these important human pathogens are needed.

When clinical material is fixed in alcohol based fixatives, it is imperative that the laboratory personnel handling such material are made aware of the possibility of infection transfer. If it is known that a clinical specimen may be contaminated with particularly resistant forms of microbes, it is recommended that formalin or glutaraldehyde fixation methods be used for the tissues collected. If aldehyde containing fixatives specifically need to be avoided, we recommend Leiden No 2 fixative for use with clinical material, though it is implicit that all the precautions normally taken in a laboratory when handling clinical material are routinely followed, irrespective of the method of fixation of the tissue.

We conclude by invoking the good sense of the laboratory manager, who must consider carefully the advantages and disadvantages of all the methods in use in the laboratory. In the case of tissue fixation methods, alcohol fixatives have many advantages (including excellent morphology of tissue, remarkable antigen recovery, lesser toxicity, and so on ${ }^{71920}$ ) and these positive features will have to be weighed against the disadvantages highlighted in this paper.

We gratefully acknowledge the technical help of Mr Robert Brown of the Department of Medical Laboratory Science, RMIT.

1 Williams PL, Burson JL. Industrial toxicology. New York: Van Nostrand Reinhold, 1985:244-5.

NIOSH Testimony on the OSHA proposed rules on air contaminants. Docket No H-020, August 1, 1988.

3 NIOSH/OSHA Occupational health guidelines for occupational hazards. US Department of Health and Human Services, publication No (NIOSH) 81-123 (1981). Available as GPO Stock No 017-033-00337-8 from Superintendent of Documents, Washington, DC 20402.

4 Singer RM. Neurotoxicity guidebook. New York: Van Nostrand Reinhold, 1990:166-78.

5 Main D, Hogan TJ. Health effects of low level exposure to formaldehyde. F Occup Med 1983;25:896-901. 6 Nordman $\mathrm{H}$, Keskinen $\mathrm{H}$, Tuppurainen M. Formaldehyde asthma-rare or

7 Boon ME, Schmidt U, Cramer-Knijnenburg GI, van Krieken JHJM. Using Kryofix as alternative for formalin results in more optimal and standardized immunostaining of paraffin sections. Pathol Res Pract 1992;188:832-5.

8 Boon ME, Kok LP. Formalin is deleterious to cystoskeleton proteins: do we need to replace it by formalin-free Kryofix? Eur $\mathcal{F}$ Morph 1991;29:173-80.

9 Rubbo SD, Gardner JF, Webb RL. Biocidal activities of glutaraldehyde and related compounds. F Appl Bacteriol 1967; 30:78-87.

10 Borick PM, Dondershine FH, Chandler JL. Alkalinized glutaraldehyde, a new antimicrobial agent. $\mathcal{F}$ Pharm Sci 1964; 53:1273-75.

11 Russell $\mathrm{AD}$. The destruction of bacterial spores. In: Hugo $\mathrm{WB}$, ed. Inhibition and destruction of the microbial cell. New York: Academic Press, 1971:451-612.

12 Russell AD. Factors influencing the efficacy of antimicrobial agents. In: Russell AD, Hugo WB, Aycliffe GAJ, eds. Principles and practice of disinfection, preservation and sterilization Oxford: Blackwell Scientific Publications, 1982:107-33. 
13 Koransky JR, Allen SD, Dowell VR. Use of ethanol for selective isolation of sporeforming microorganisms. Appl Environ Microbiol 1978; 35:762-5.

14 Beaman TC, Pankratz HS, Gerhardt P. Heat shock affects permeability and resistance of Bacillus stearothermophilus spores. Appl Environ Microbiol 1988;54:2515-20.

15 De Santis EP, Mazzette R. Rivelazione di chemoantibiotici con tests microbiologici: valutazione dei limiti di sensibilita. Boll Soc Ital Biol Sper 1991;67:561-8.

16 Mecke P, Christiansen B, Pirk A. Zur Eignung handelsublicher Bioindicatoren mit Sporen von B stearothermophilus für die Prufung von Formaldehyd-Gas Sterilisatoren. Zentralbl Hyg Umweltmed 1991;192:25-32.

17 Russell AD. Bacterial spores and chemical sporicidal agents. Clin Micro Rev 1990;3:99-119.

18 Briggs A, Yazdany ZZ. Resistance of Bacillus spores to combined sporicidal treatments. $\mathcal{F}$ Appl Bacteriol 1974;37:623 31 .

19 Kok LP, Boon ME, Suurmeijer AJH. Major improvements in microscopic-image quality of cryostat sections. Am $\mathrm{fClin}$ Pathol 1987;88:620 Leyden: Coulomb Press, 1988. 